\title{
Antiproliferative effect of apocynin in cervical epithelial cells infected by HPV 16 involves change of ROS production and cell cycle
}

\author{
Natália Alves Lima ${ }^{1}$ - Natália de Carvalho Scharf Santana ${ }^{1}$ Nayara Cristina Alves de Lima ${ }^{1}$ \\ Danielle Lazarin-Bidóia ${ }^{2}$ Patrícia de Souza Bonfim-Mendonça ${ }^{3}$ Tânia Ueda Nakamura ${ }^{4}$. \\ Celso Vataru Nakamura ${ }^{4}$ Marcia Edilaine Lopes Consolaro ${ }^{5}$ - Valdecir Farias Ximenes ${ }^{6}$. \\ Sueli de Oliveira Silva ${ }^{4}$
}

Received: 11 July 2016 / Accepted: 6 July 2017 / Published online: 19 July 2017

(C) Springer Science+Business Media, LLC 2017

\begin{abstract}
The cervical cancer is characterized as a public health problem. The human papillomavirus, especially the high-risk types 16 and 18, is present in $99.7 \%$ of cases of invasive cervical cancers. Due to high prevalence, the search for new drugs for the treatment is continuous. The apocynin, compound belonging to the class of catecholmethoxy acetophenone, has been used as an effective and non-toxic inhibitor of the NADPH oxidase complex, in many experimental models. Some early studies have indicated that apocynin also exerts antiproliferative activity inducing cell death by apoptosis. Thus, we evaluated the effect of apocynin in cervical epithelial cells infected by human papillomavirus 16 ( $\mathrm{SiHa}$ cells) by analyzing oxygen species production, cell cycle, cell morphology, cell
\end{abstract}

Sueli de Oliveira Silva

lautenschlager@uem.br

1 Programa de Pós-graduação em Biociências Aplicadas á Farmácia, Universidade Estadual de Maringá, Av. Colombo, 5.790, Maringá PR CEP 87020-900, Brazil

2 Programa de Pós-graduação em Ciências Farmacêuticas, Universidade Estadual de Maringá, Av Colombo, 5.790, Maringá PR CEP 87020-900, Brazil

3 Programa de Pós-graduação em Ciências da Saúde, Universidade Estadual de Maringá, Av Colombo, 5.790, Maringá PR CEP 87020-900, Brazil

4 Departamento de Ciências Básicas da Saúde, Universidade Estadual de Maringá, Av. Colombo, 5.790, Maringá PR CEP 87020-900, Brazil

5 Departamento de Análises Clínicas e Biomedicina, Universidade Estadual de Maringá, Av. Colombo, 5,790, Maringá PR CEP 87020-900, Brazil

6 Departamento de Química, Faculdade de Ciências, Universidade Estadual Paulista Júlio de Mesquita Filho, Av Eng Luiz Edmundo Carrijo Coube, Bauru SP S/N CEP 17033360, Brazil volume, membrane integrity and mitochondria membrane potential. Our data showed that apocynin induces antiproliferative effects by decreasing reactive oxygen species production and inducing cell cycle arrest, activating pathways that induce apoptosis cell death.

Keywords $\mathrm{SiHa} \cdot \mathrm{HPV} 16 \cdot$ Apocynin $\cdot$ Reactive oxygen species

\section{Introduction}

Cancer of the cervix is the second most gynecologic malignancy among women, accounting for approximately $12 \%$ of all female cancers (Pisani et al. 2002). According to the latest report from the International Agency for Research on Cancer/WHO, the incidence was estimated to be 12.7 million new cases annually, with a mortality rate of around 7.6 million people worldwide each year (INCA 2012). The human papillomavirus (HPV) is present in $99.7 \%$ of cases of invasive cervical cancers (Dunne et al. 2007; Spangle and Munger 2010). Studies have shown that HPV, especially the carcinogenic high-risk genotypes 16 and 18, are etiologically related to cervical cancer (Pilch et al. 2001). Factors such as suppression of apoptosis and cell adesion appear to play an important role in the development of pathogenesis (DeFilippis et al. 2003).

Reactive oxygen species (ROS) are produced by mitochondria, peroxisomes, cytochrome P-450 and other cell components such as NADPH oxidase. ROS are essential players in many physiological signaling events, however the excessive production of ROS has been implicated in the progression of many diseases (Bedard and Krause 2007). For example, in many types of tumors ROS play an 
important role in the first steps of carcinogenesis and tumor progression by inducing DNA damage and cellular alteration such as up regulation of growth factors (Lee et al. 2006).

In recent years, studies have been conducted demonstrating a broad spectrum of action of apocynin, a methoxysubstituted catechol that inhibits the production of ROS by NADPH oxidase through the disruption of NADPH oxidase complex assembly (Barbieri et al. 2004). This complex is involved in important signaling pathways, including cell growth, cell survival and cell death (Bedard and Krause (2007); Stefanska and Pawliczak 2008). Studies also demosntrate the effect of apocynin on cancer cell lines such as, prostate cancer, with decrease in oxidative stress, antiproliferative effect and increase in the number of apoptotic cell death (Suzuki et al. 2013).

Due to the high incidence of cervical cancer caused by the HPV 16 the present study investigated cell alterations induced by apocynin in SiHa cells (HPV 16). Our data showed that apocynin induces a decrease of reactive oxygen species production in cervical neoplastic cells immortalized by HPV 16 triggering biochemical alterations that lead to cell cycle arrest and antiproliferative effects.

\section{Materials and methods}

\section{Preparation of apocynin}

The stock solution of apocynin (Sigma-Aldrich Chemical Co. St. Louis, MO, USA) were prepared in dimethyl sulfoxide (DMSO) $60 \mathrm{mM}$ followed by sonication, sonicator (Sonics, USA). The solution was diluted in DMEM at final concentrations of $10,50,100,250$, and $500 \mu \mathrm{M}$ for use in subsequent experiments so that the final DMSO concentration did not exceed $1 \%$.

\section{Cell culture}

Cervical neoplastic epithelial cells (SiHa cell, HPV-16 positive) donated by Dr. Luísa Lina Villa, ICESP-USP, São Paulo, Brazil, and African green monkey kidney Cercopithecusa ethiops ATCC CCL-81(VERO) were grown in DMEM medium supplemented with $5000 \mu \mathrm{g}$ streptomycin and $125 \mu \mathrm{g}$ amphotericin $\mathrm{B}$ and $10 \% \mathrm{FBS}$ at $37^{\circ} \mathrm{C}$ in $\mathrm{CO}_{2}$ incubator. After confluence and the cell monolayer formation, cells were trypsinized for $1 \mathrm{~min}$, resuspended in DMEM containing $10 \%$ FCS and transferred into new plastic bottles.

\section{Cell viability and toxicity assay}

A suspension of SiHa and Vero cells were plated in DMEM with $10 \%$ bovine fetal serum and antibiotics in 96-well plates at a concentration of $5.0 \times 10^{5}$ cells $/ \mathrm{ml}$. The plate was incubated for $24 \mathrm{~h}$ at $37^{\circ} \mathrm{C}$ in $5 \% \mathrm{CO}_{2}$. The monolayer obtained after $24 \mathrm{~h}$ was treated with different concentrations ranging from 10 to $500 \mu \mathrm{M}$ apocynin, and its respective controls. After incubation at $37{ }^{\circ} \mathrm{C}$ with $5 \% \mathrm{CO}_{2}$ for $48 \mathrm{~h}$ ( $\mathrm{SiHa}$ ) and $72 \mathrm{~h}$ (VeRo) the cells were evaluated by the method of 3-(4,5-dimethyl-2-thiazolyl) -2,5-diphenyl-2Htetrazolium bromide (MTT), used to assess cytotoxicity and incubated for $4 \mathrm{~h}$. Intracellular formazan crystals formed by the metabolism of MTT were solubilized with dimethyl sulphoxide and the absorbance of the solution was measured at $570 \mathrm{~nm}$ in a spectophotometer (Bio Tek-Power Wave XS). The percentage of viability was calculated as (optical density (OD) of the cultures with treatment/DO control sample) $\times 100 \%$.

\section{Treatment concentrations}

On the basis of MTT results, two different doses $\mathrm{IC}_{50}(50 \%$ inhibitory concentration) and $\mathrm{IC}_{90}$ (90\% inhibitory concentration) of apocynin were selected for further experiments. Control groups received only media without any apocynin treatment. Cells treated with apocynin were incubated for $48 \mathrm{~h}$ in $\mathrm{CO}_{2}$ incubator at $37^{\circ} \mathrm{C}$ for all experiments.

\section{Measurement of total ROS production}

ROS production was evaluated after exposure of SiHa cells $\left(5.0 \times 10^{5}\right.$ cells $\left./ \mathrm{ml}\right)$ to apocynin using $2^{\prime}, 7^{\prime}$-dichlorodihydrofluorescein diacetate (H2DCF-DA) as a detector of intracellular ROS. H2DCF-DA can be converted by intracellular esterase to $\mathrm{H} 2 \mathrm{DCF}$, which is oxidized by ROS to highly fluorescent DCF. The cells were washed twice in Hanks' Balanced Salt Solution (HBSS) and incubated with $10.0 \mathrm{mM}$ DCFH-DA in HBSS in $5 \% \mathrm{CO}_{2}$ at $37^{\circ} \mathrm{C}$ for $30 \mathrm{~min}$. Then, the cells were washed twice again in HBSS and incubated with HBSS buffer with iron free or iron supplemented medium. After, the SiHa cells were treated with apocynin for $48 \mathrm{~h}$ at $37^{\circ} \mathrm{C}$, washed twice with HBSS and read. Total ROS were measured as an increase in fluorescence that is caused by the conversion of nonfluorescent dye to highly fluorescent $2^{\prime}, 7^{\prime}$-dichlorofluorescein (DCF) in a fluorescence microplate reader (Victor X3, Perki$\mathrm{nElmer}$ ) at $\lambda$ excitation $=488 \mathrm{~nm}$ and $\lambda$ emission $=530 \mathrm{~nm}$.

\section{Analysis of cell cycle}

Cell cycle was evaluated after exposure of SiHa cells $(5.0 \times$ $10^{5}$ cells $/ \mathrm{ml}$ ) to apocynin for $48 \mathrm{~h}$ at $37^{\circ} \mathrm{C}$. Then, the cells were suspended in phosphate-buffered saline (PBS) and fixed by addition of $70 \%$ ice cold methanol. The fixed cells were harvested, and washed with PBS and RNase $(1 \mu \mathrm{g} / \mu \mathrm{l})$ was added to the samples and the cells re-suspended in PI staining $(10 \mu \mathrm{g} / \mathrm{ml})$. Data acquisition and analysis were performed using a FACS Calibur flow cytometer equipped with 
CellQuest software. A total of 10,000 events were acquired in the region that was previously established as the one that corresponded to the SiHa cells.

\section{Microscopy analysis}

Morphology was evaluated in SiHa cells $\left(5.0 \times 10^{5}\right.$ cells/ $\mathrm{ml}$ ) seeded in 6-well plates with apocynin after $48 \mathrm{~h}$. The cells were observed under a differential interference contrast (DIC) microscopy (Axiscope plus 2, Zeiss, Germany) and compared with the control group.

\section{Cell volume determination}

Cell volume was evaluated after exposure of $\mathrm{SiHa}$ cells $\left(5.0 \times 10^{5}\right.$ cells $\left./ \mathrm{ml}\right)$ to apocynin for $48 \mathrm{~h}$ at $37^{\circ} \mathrm{C}$. Then, the cells were collected by centrifugation, washed twice in PBS, resuspended in PBS, and analyzed using fluorescenceactivated cell sorting and a FACSCalibur flow cytometer. Actinomycin D (20.0 mM) was used as a positive control. A total of 10,000 events were acquired in the region that was previously established as the one that corresponded to the $\mathrm{SiHa}$ cells. Histograms were generated, and the analysis was performed using CellQuest software; forward light scatter (FSC-H) representes the cell volume.

\section{Cell membrane integrity assay}

Cell membrane integrity was evaluated after exposure of SiHa cells $\left(5.0 \times 10^{5}\right.$ cells $\left./ \mathrm{ml}\right)$ to apocynin for $48 \mathrm{~h}$ at $37^{\circ} \mathrm{C}$ using propidium iodide (PI), a probe that binds to DNA of ruptured membrane cells. Afterward, the SiHa cells were washed twice in PBS and incubated with $0.2 \mathrm{mg} / \mathrm{ml}$ PI for $10 \mathrm{~min}$ to verify cell membrane integrity. Digitonin (40.0 $\mathrm{mM}$ ) was used as a positive control. Data acquisition and analysis were performed using a FACSCalibur flow cytometer equipped with CellQuest software. A total of 10,000 events were acquired in the region that was previously established as the one that corresponded to the SiHa cells. Alterations in the fluorescence of PI were quantified as the percentage of increase in the fluorescence compared with the control (untreated SiHa cells).

\section{Mitochondrial membrane potential assay}

Mitochondrial membrane potential was evaluated after exposure of SiHa cells $\left(5.0 \times 10^{5}\right.$ cells $\left./ \mathrm{ml}\right)$ to apocynin in DMEM medium for $48 \mathrm{~h}$ at $37^{\circ} \mathrm{C}$, using the fluorescent probe Rh123, which accumulates with in mitochondria. Afterward, the SiHa cells were washed twice, suspended in $0.9 \%$ saline and incubated with $5 \mathrm{mg} / \mathrm{ml} \mathrm{Rh} 123$ for $15 \mathrm{~min}$. Control cell cycle progression (CCCP) (100.0 mM) was used as a positive control. The data acquisition and analysis were performed using a FACSCalibur flow cytometer (Becton-Dickin-son, Rutherford, NJ, USA) equipped with CellQuest software (Joseph Trotter, The Scripps Research Institute, La Jolla, CA, USA). The wavelength for excitation was $507 \mathrm{~nm}$ and for emission was $529 \mathrm{~nm}$. A total of 10,000 events were acquired in the region that was previously established as the one that corresponded to the SiHa cells. Alterations in Rh123 fluorescence were quantified using an index of variation (IV) obtained from the equation (MT_MC)/MC, in which MT is the median fluorescence for the treated $\mathrm{SiHa}$ cells and MC is the median fluorescence for the control SiHa cells. Negative IV values correspond to depolarization of the mitochondrial membrane.

\section{Statistical analysis}

Statistical analysis of results (GraphPad Prism version 4.00 for Windows, GraphPad Software, San Diego, CA, USA) was performed by one-way analysis of variance (ANOVA) followed by the Newman-Keuls multiple comparison test or by two-way ANOVA when the effects of two different factors were studied in the same experiment. The results were obtained from three independent experiments and the bar represents the mean \pm SE. $* P$-values of $<0.05$ were considered significant.

\section{Results and discussion}

\section{Apocynin induces antiproliferative effects in SiHa cells}

Apocynin was initially tested against $\mathrm{SiHa}$ cells to reveal its cytotoxicity. For this, we first performed MTT assay, a classic method to assess cell proliferation. The results indicated a progressive inhibition of $\mathrm{SiHa}$ cells proliferation in a dependent concentration (Fig. 1). The $\mathrm{IC}_{50}$ and $\mathrm{IC}_{90}$ value after $48 \mathrm{~h}$ of incubation was 228.5 and $457.1 \mu \mathrm{M}$, respectively. For VeRo cells apocynin was less toxic in all tested concentrations with an CC50 (50\% cytotoxic concentration) of $374.9 \mu \mathrm{M}$. Similar antiproliferative effects of apocynin in prostate cancer cells has been previously described (Suzuki et al. 2013). To explore the mechanism of apocynin induced antiproliferative effect in SiHa cells, we performed additional biochemical and morphological analysis in apocynin-treated SiHa cells.

\section{Apocynin decreases total ROS production in SiHa cells}

ROS are generated in cervical epithelial cells, the target cells for HPV 16 infection, by several mechanisms, including by the NADPH oxidase complex (Benedyk et al. 2007). Cancer cells commonly have a pro-oxidative activity as a consequence of many factors such as the inflammatory reactions that are associated with the continuous activation 
of the NADPH oxidase by inflammatory mediators (Munoz et al. 2004; Hopfl et al. 2000). Thus, we evaluate the total ROS production in $\mathrm{SiHa}$ cells treated with apocynin, a

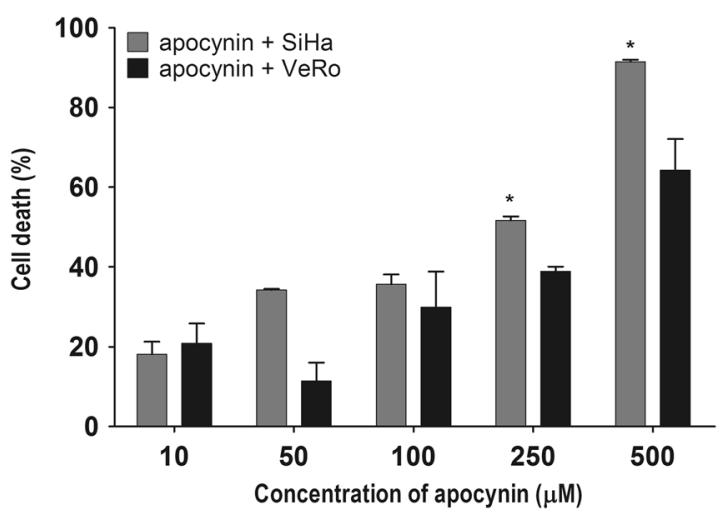

Fig. 1 Analysis of cytotoxic potentials of apocynin. Cells cultured in presence of various concentrations of apocynin $(10-500 \mu \mathrm{M})$ for $48 \mathrm{~h}$. Cell proliferation was measured using MTT assay. $* P \leq 0.05$ indicates significant difference between the apocynin-treated VeRo cells and apocynin-treated cells

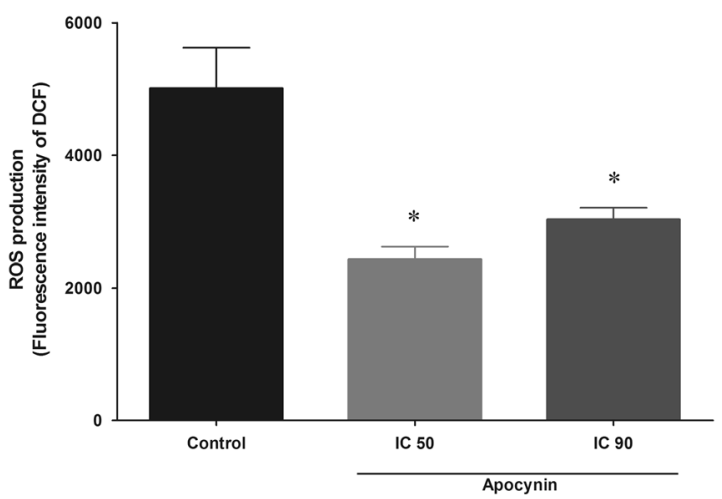

Fig. 2 Total ROS production in apocynin-treated SiHa cells. Total ROS production was measured in cells stained with $\mathrm{H}_{2}$ DCF-DA and analyzed by fluorescence intensity of DCF. SiHa cells $\left(5.0 \times 10^{5}\right.$ cells/ $\mathrm{ml}$ ) were treated with $\mathrm{IC}_{50}: 228.5$ and $\mathrm{IC}_{90}: 457.1 \mu \mathrm{M}$ apocynin for 48 h. $* P \leq 0.05$ indicates significant difference between the control group (untreated cells) and apocynin treated samples standard NADPH oxidase inhibitor, using flow cytometry, in which the nonfluorescent H2DCF-DA is oxidized by ROS, producing fluorescent DCF. As expected, Fig. 2 shows that apocynin induced a significant decrease in intracellular oxidant species formation by $\mathrm{SiHa}$ cells at both concentrations tested after $48 \mathrm{~h}$ of treatment compared with the control group. For $\mathrm{IC}_{50}$ treated cells the decrease was $51.5 \%$ and for $\mathrm{IC}_{90}$ the decrease was $39.6 \%$. This effect of apocynin was already described for other cancers cells such as prostate cancer cells (Suzuki et al. 2013). Additionally, several studies have shown that the use of antioxidants therapy has an inhibitory effect on tumor progression (Zhang et al. 2002).

\section{Apocynin arrests SiHa cells cycle}

The cell cycle is a conserved mechanism responsible for cell duplication that involves a series of events performed by cyclins and cyclin dependent kinases (MacLachlan et al. 1995). It has been described that low level of ROS can CCCP through the expression and activity of these enzymes (Qin et al. 2011). However, high level of ROS results in dysregulation of the cell cycle components inducing tumor formation (Freinbichler et al. 2011). Based on our previous results, we evaluate the effect of apocynin on $\mathrm{SiHa}$ cell cycle, using PI, a probe that binds to DNA. Cell cycle analysis indicated that apocynin, at both concentrations tested, induced a similar effect in $\mathrm{SiHa}$ cell in sub-G0/G1 phase and in $\mathrm{G} 2 / \mathrm{M}$ phase revealing a growth arrested population and a population undergoing cell death. As shown in Fig. 3 the cells showed a significant increase in sub-G0/G1 phase (94\% for fig B and $89 \%$ for fig C) (cells with DNA fragmentation) (Mohan et al. 2010) and a significant decrease (40\% for fig B and $39 \%$ for fig C) in the subpopulation of cells in the G2/M phase (DNA duplicated) compared with the control group (Fig. 3b, c). These data might be related to the inhibition of the NADPH oxidase system by apocynin which reduces the ROS level resulting
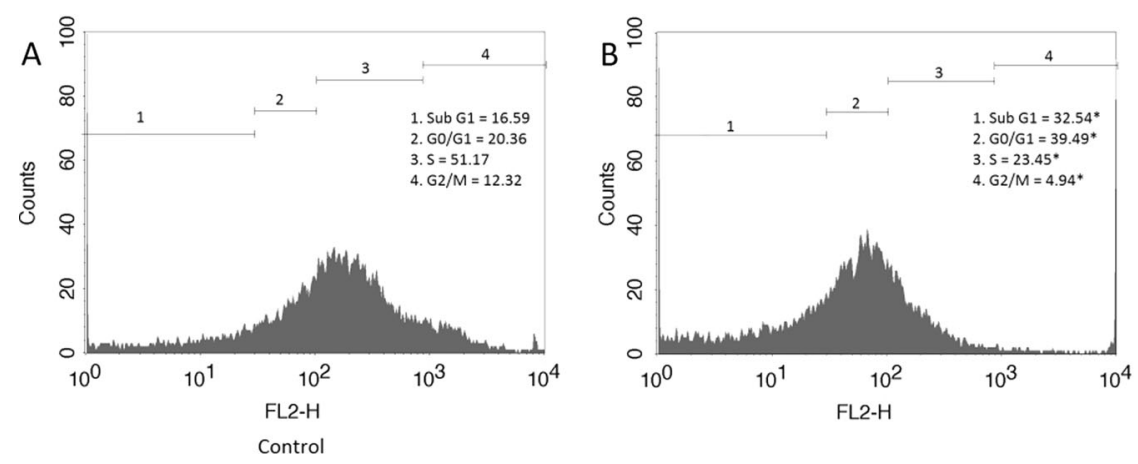

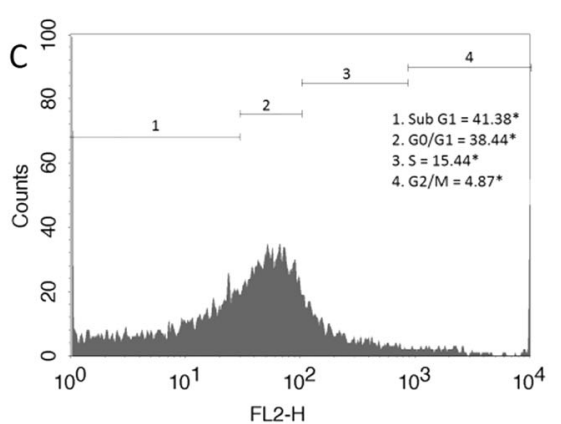

Fig. 3 Cell cycle in apocynin-treated SiHa cells $\left(5.0 \times 10^{5}\right.$ cells $\left./ \mathrm{ml}\right)$ using flow cytometry analysis. a Untreated $\mathrm{SiHa}$ cells. b, c SiHa cells treated with $\mathrm{IC}_{50}: 228.5$ and $\mathrm{IC}_{90}: 457.1 \mu \mathrm{M}$ apocynin, respectively for
$48 \mathrm{~h} . * P \leq 0.05$, indicates significant difference between the control group (untreated cells) and apocynin treated samples 
in cell arrest. Furthermore, the use of antioxidants therapy has shown to inhibit cyclin leading to $\mathrm{G} 1$ phase arrest (Zhang et al. 2002).

\section{Apocynin induces morphological changes in SiHa cells related to apoptosis}

The cytotoxic effects of apocynin might also induce morphological alterations on $\mathrm{SiHa}$ cells as a reflect of the changes at metabolic level. Thus, we evaluated the effect of apocynin on $\mathrm{SiHa}$ cell morphology, using phase microscope of interference contrast difference (DIC). As shown in Fig. 4 apocynin induced apoptotic-like cell death morphology in $\mathrm{SiHa}$ cells in a dose-dependent manner. At $\mathrm{IC}_{90}$, apoptotic round-shaped and shrinked cells (arrow) were observed all around (Fig. 4c), compared with the control group (Fig. 4a). Apoptosis is characterized by distinctive morphological features and is essential to maintain tissue growth homeostasis ( $\mathrm{Yu}$ and Choi 2000). Cancer cells are known to have deregulated cell proliferation and suppression of
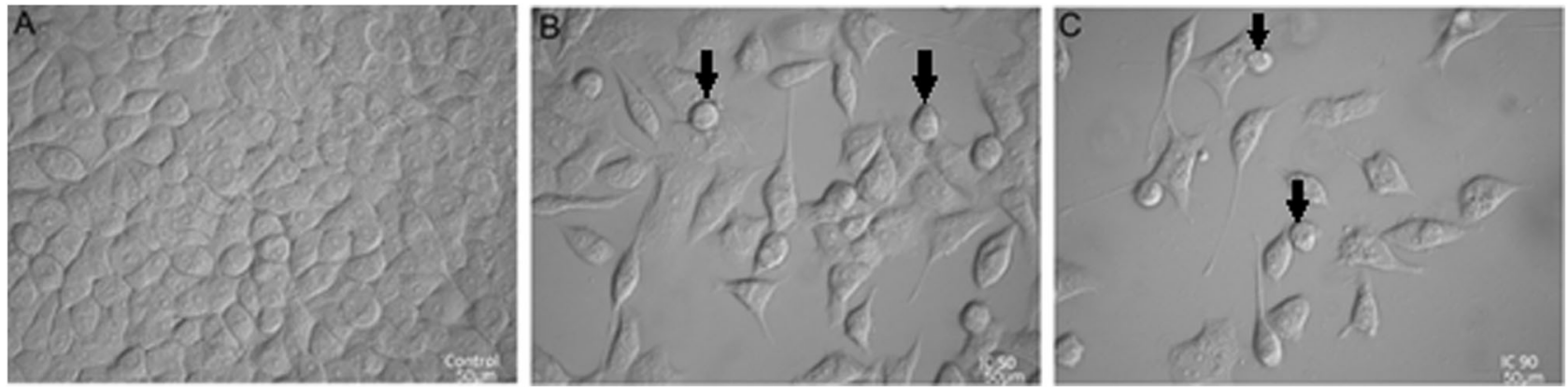

Fig. 4 Morphological changes in apocynin-treated SiHa cells $(5.0 \times$ $105 \mathrm{cells} / \mathrm{ml})$ using microscope of interference contrast difference $(\times 400)$. a Untreated SiHa cells. b, c SiHa cells treated with $\mathrm{IC}_{50}: 228.5$ and
$\mathrm{IC}_{90}: 457.1 \mu \mathrm{M}$ apocynin, respectively for $48 \mathrm{~h}$. Scale bar $50 \mu \mathrm{M}$. At $\mathrm{IC}_{90}$, apoptotic round-shaped and shrinked cells (arrow) were observed all around (Fig. 4c), compared with the control group (Fig. 4a)
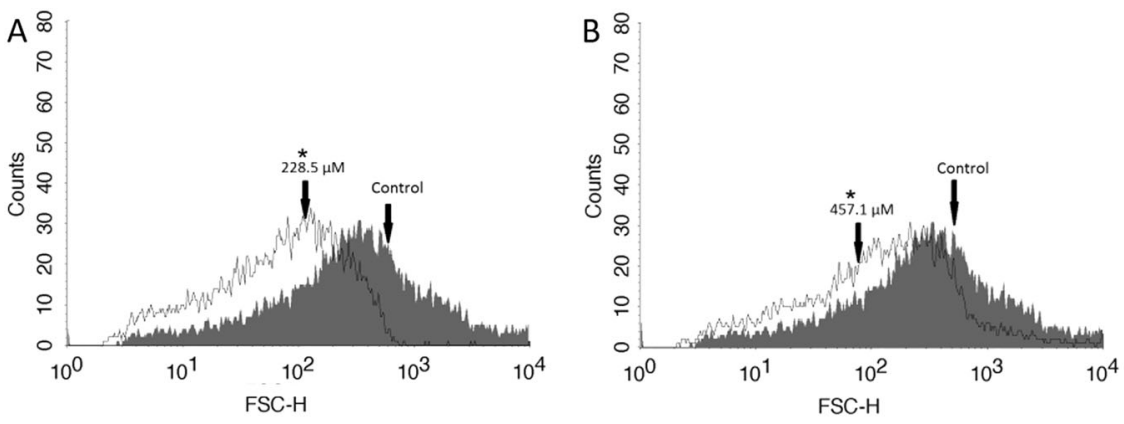

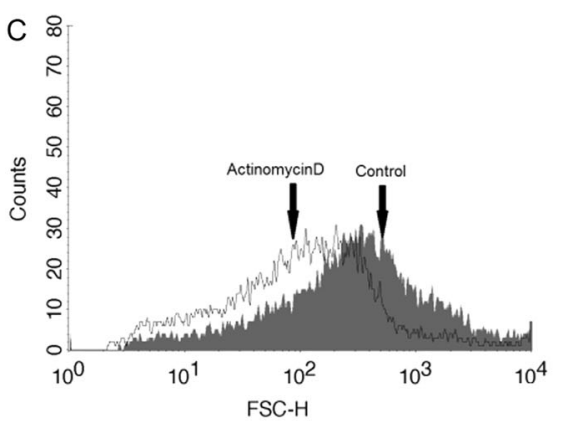

Fig. 5 Cell volume in apocynin-treated $\mathrm{SiHa}$ cells $\left(5.0 \times 10^{5}\right.$ cells / $\mathrm{ml})$ using flow cytometry analysis. a $\mathrm{SiHa}$ cells treated with $\mathrm{IC}_{50}$ : $228.5 \mu \mathrm{M}$. b SiHa cells treated with $\mathrm{IC}_{90}: 457.1 \mu \mathrm{M}$ for $48 \mathrm{~h}$. c SiHa cells treated with $20 \mu \mathrm{M}$ actinomycin D for $48 \mathrm{~h}$. FSC-Height was considered as a function of cell size. Arrows correspond to apocynin concentrations tested. $* P \leq 0.05$, indicates significant difference between the control group (untreated cells) and apocynin treated samples
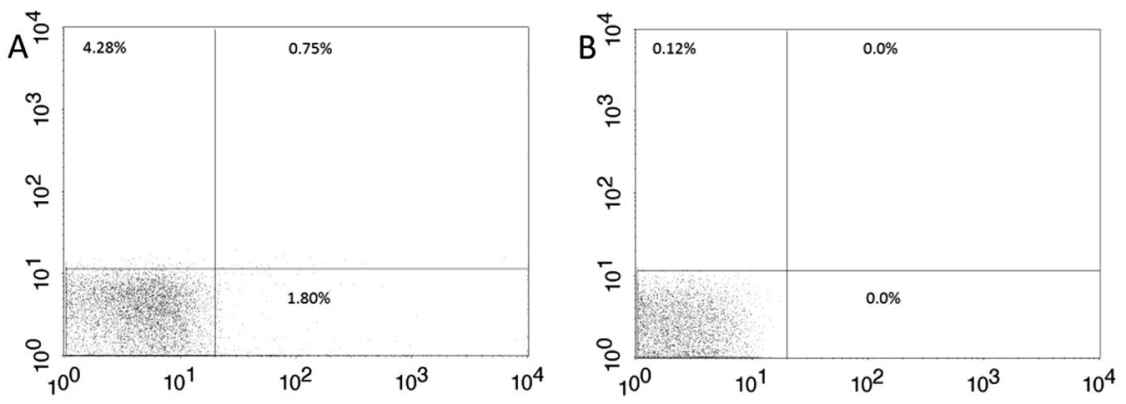

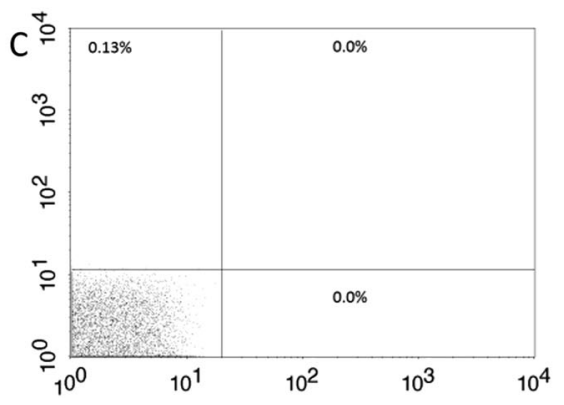

cells treated with $\mathrm{IC}_{50}: 228.5$ and $\mathrm{IC}_{90}: 457.1 \mu \mathrm{M}$, respectively for $48 \mathrm{~h}$. Percentage of PI-stained positive cells is shown in the upper right and left quadrants
Fig. 6 Cell membrane integrity in apocynin-treated $\mathrm{SiHa}$ cells $(5.0 \times$ $10^{5}$ cells $\left./ \mathrm{ml}\right)$. Cell membrane integrity was measured using flow cytometry in cells stained with PI. a Untreated SiHa cells. b, c SiHa 
apoptosis which support tumor progression (Okada and Mak 2004).

\section{Apocynin decreases SiHa cells volume}

To confirm the morphological alterations induced by apocynin on $\mathrm{SiHa}$ cells we analyzed SiHa cells volume. All the cells have a well-defined mechanism to maintain a constant and normal cell volume (Koeppen and Stanton 2007). Any stress that changes the cell tonicity will affect cell volume and the cells will shrink or swell. Thus, we evaluate the effect of apocynin on $\mathrm{SiHa}$ cells volume using flow cytometry. As shown in Fig. 5, there was a decrease in cell volume on $\mathrm{SiHa}$ cells in both concentrations tested of apocynin after $48 \mathrm{~h}$, with reductions around 75 and $57 \%$ for $228.5 \mu \mathrm{M}$ and $457.1 \mu \mathrm{M}$ of apocynin (Fig. 5a, b), respectively compared with the control group. The positive control, actinomycin D, decreased cell volumes 64\%. This effect will certainly affect the normal cell morphology and function and might be a signal for cell death. In fact, cell shrinkage is a known hallmark of apoptosis ( $\mathrm{Yu}$ and Choi 2000).

Table 1 Mitochondrial membrane potential assay in $\mathrm{SiHa}$ cells treated with apocynin for $48 \mathrm{~h}$ and stained with Rh123

\begin{tabular}{lcr}
\hline $\mathrm{SiHa}$ & Median & \multicolumn{1}{c}{$\mathrm{IV}^{\mathrm{a}}$} \\
\hline $\mathrm{M}$ & 1893.4 & 0.0 \\
Control & $598.89^{*}$ & -0.6 \\
228.56 & $54.25^{*}$ & -0.9 \\
457.12 & & \\
\hline
\end{tabular}

a $\mathrm{IV}=\left(M_{\mathrm{T}}-M_{\mathrm{C}}\right)$, where $M_{\mathrm{T}}$ corresponds to the median the fluorescence for treated $\mathrm{SiHa}$ cells and $M_{\mathrm{C}}$ to that for control SiHa cells ${ }^{*} P \leq 0.05$, significant difference relative to the control group (untreated cells)
Apocynin does not alter SiHa cells membrane integrity

The cell membrane controls the entry and exit of substances maintaining the homeostasis inside the cell (Koeppen and Stanton 2007). Thus, assessing cell membrane integrity will certainly measure cell viability and cytotoxic effects. Thus, we evaluated the effect of apocynin on SiHa cells membrane integrity using PI, a probe that is excluded from healthy cells but binds to DNA in ruptured membrane cells. According to Fig. 6, apocynin does not affect the membrane integrity of SiHa cells after $48 \mathrm{~h}$ of treatment, compared with the control group. The histograms show, at both concentrations tested, the same intensity of PI fluorescence of control group (Fig. 6a, b), indicating no alterations of cell membrane integrity. Bright fluorescence was observed with the positive control, digitonin (data not shown). Thus, apocynin might be inducing other alterations, instead of membrane rupture, in $\mathrm{SiHa}$ cells that trigger cytotoxic and antiproliferative effects. However, it is important to highlight that cell membrane integrity is another known hallmark of apoptosis which might be a SiHa cell death pathway induced by apocynin (Liu et al. 2015).

\section{Apocynin induces mitochondrial membrane potential alterations in SiHa cells}

Mitochondria are essential organelles within the cell in which a number of biochemical reaction take place, including the energy production and the regulation of cell death by apoptosis (Mejia and Hatch 2015). Thus, dysfunction of the mitochondria will certainly result in cell function alteration that might ends with cell death. Based on our previous result we evaluate the $\Delta \Psi \mathrm{m}$ in apocynintreated SiHa cells stained with Rh 123, in which Rh123 accumulates within normal mitochondria using flow cytometry. Histograms of total Rh123 fluorescence showed a marked decrease in fluorescence intensity, indicating that
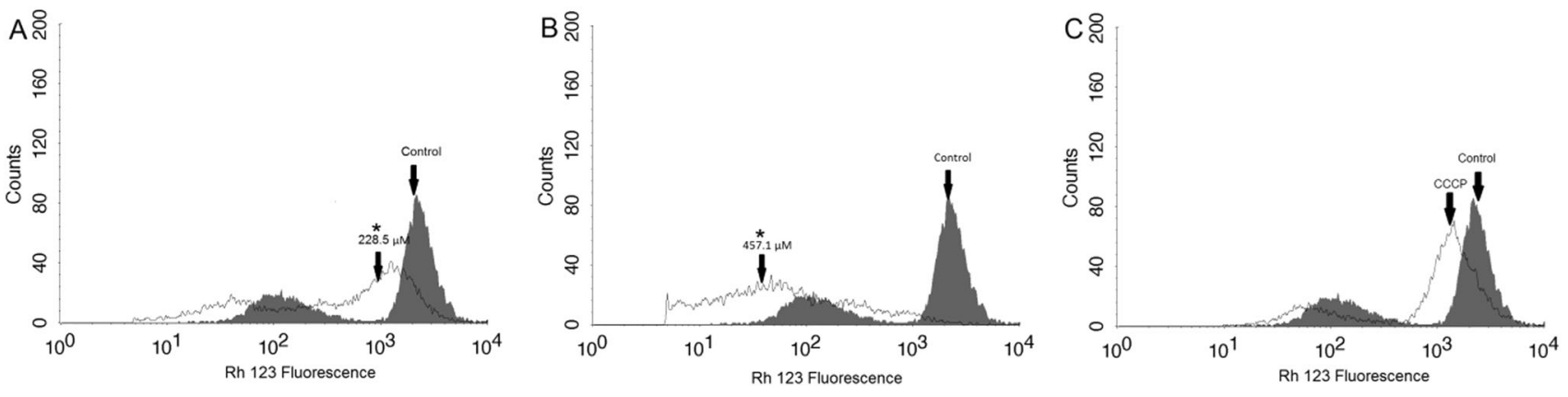

Fig. 7 Mitochondrial membrane potential in apocynin-treated $\mathrm{SiHa}$ cells. Mitochondrial membrane potential was measured in cells stained with Rh123, which accumulates within mitochondria and analyzed by fluorescence intensity of Rh123. a SiHa cells $\left(5.0 \times 10^{5}\right.$ cells $\left./ \mathrm{ml}\right)$ treated with $\mathrm{IC}_{50}: 228.5 \mu \mathrm{M}$ apocynin. b SiHa cells treated with $\mathrm{IC}_{90}$ :
$457.1 \mu \mathrm{M}$ apocynin for $48 \mathrm{~h}$. c SiHa cells treated with $100 \mathrm{mM} \mathrm{CCCP}$ for $48 \mathrm{~h}$. Arrows correspond to concentrations tested. $* P \leq 0.05$, indicates significant difference between the control group (untreated cells) and apocynin treated samples 
the mitochondria were depolarized in $\mathrm{SiHa}$ cells treated with 228.5 and $457.1 \mu \mathrm{M}$ of apocynin for $48 \mathrm{~h}$. As shown in Table 1 and Fig. 7, the reductions of $\Delta \Psi \mathrm{m}$ were 68 and $97 \%$ for 228.5 and $457.1 \mu \mathrm{M}$ of apocynin, respectively compared with the control group. The positive control, CCCP, induced $36 \%$ the reductions changes in mitochondrial membrane potential. Other anticancer drug has also shown effects on mitochondria as well as inducing cell death, inhibition of cell cycle/proliferation (Kuznetsov et al. 2011).

\section{Conclusion}

Our data showed that apocynin induces antiproliferative effects on SiHa cells by decreasing ROS production and inducing cell cycle arrest, activating pathways that induce cell death by apoptosis. We believe that the effect of apocynin on SiHa cells is closely related to ROS decrease, which might be associated to the inhibition of the NADPH oxidase system by apocynin, a known inhibitor of NADPH oxidase (Barbieri et al. 2004), inducing cell detention in phase G1 (Mohan et al. 2010). Thus, the use of antioxidant therapy might induce an interesting inhibitory effect in tumor progression of cervical cancer (Zhang et al. 2002).

Acknowledgements This study was supported by Conselho Nacional de Desenvolvimento Científico e Tecnológico (CNPq), Coordenação de Aperfeiçoamento de Pessoal de Nível Superior (Capes), Fundação Araucária. Programa de Pós Graduação em Biociências Aplicadas a Farmácia da Universidade Estadual de Maringá.

\section{Compliance with ethical standards}

Conflict of interest The authors declare that they have no competing interests.

\section{References}

Barbieri SS, Cavalca V, Eligini S, Brambilla M, Caiani A, Tremoli E, Colli S (2004) Apocynin prevents cyclooxygenase 2 expression in human monocytes through NADPH oxidase and glutathione redox-dependent mechanisms. Free Radic Biol Med 37 (2):156-165

Bedard K, Krause KH (2007) The NOX family of ROS-generating NADPH oxidases: physiology and pathophysiology. Physiol Rev 87(1):245-313

Benedyk M, Sopalla C, Nacken W, Bode G, Melkonyan H, Banfi B, Kerkhoff C (2007) HaCaT keratinocytes overexpressing the S100 proteins S100A8 and S100A9 show increased NADPH oxidase and NF-kappaB activities. J Invest Dermatol 127(8):2001-2011

DeFilippis RA, Goodwin EC, Wu L, DiMaio D (2003) Endogenous human papillomavirus E6 and E7 proteins differentially regulate proliferation, senescence, and apoptosis in HeLa cervical carcinoma cells. J Virol 77(2):1551-1563
Dunne EF, Unger ER, Sternberg M, McQuillan G, Swan DC, Patel SS, Markowitz LE (2007) Prevalence of HPV infection among females in the United States. JAMA 297(8):813-819

Freinbichler W, Colivicchi MA, Stefanini C, Bianchi L, Ballini C, Misini B, Weinberger P, Linert W, Vareslija D, Tipton KF, Della Corte L (2011) Highly reactive oxygen species: detection, formation, and possible functions. Cell Mol Life Sci 68 (12):2067-2079

Hopfl R, Heim K, Christensen N, Zumbach K, Wieland U, Volgger B, Widschwendter A, Haimbuchner S, Muller-Holzner E, Pawlita M, Pfister H, Fritsch P (2000) Spontaneous regression of CIN and delayed-type hypersensitivity to HPV-16 oncoprotein E7. In Lancet, England, p 1985-1986

INCA (2012) Incidência de Câncer no Brasil. [Internet]. http://www. inca.gov.br/estimativa/2012/index.asp?ID $=2015$. Accessed 10 Sept 2015

Koeppen BM, Stanton BA (2007) Regulation of body fluid osmolality: regulation of water balance. Renal Physiol 24:3263.

Kuznetsov AV, Margreiter R, Amberger A, Saks V, Grimm M (2011) Changes in mitochondrial redox state, membrane potential and calcium precede mitochondrial dysfunction in doxorubicin-induced cell death. Biochim Biophys Acta 1813 (6): 1144-1152

Lee YJ, Lee JH, Han HJ (2006) Extracellular adenosine triphosphate protects oxidative stress-induced increase of p21(WAF1/Cip1) and $\mathrm{p} 27(\mathrm{Kip} 1)$ expression in primary cultured renal proximal tubule cells: role of PI3K and Akt signaling. J Cell Physiol 209 (3):802-810

Liu Z, Liu Y, Peng D (2015) Carboxylation of multiwalled carbon nanotube attenuated the cytotoxicity by limiting the oxidative stress initiated cell membrane integrity damage, cell cycle arrestment and death receptor mediated apoptotic pathway. J Biomed Mater Res A

MacLachlan TK, Sang N, Giordano A (1995) Cyclins, cyclindependent kinases and cdk inhibitors: implications in cell cycle control and cancer. Crit Rev Eukaryot Gene Expr 5(2):127-156

Mejia EM, Hatch GM (2015) Mitochondrial phospholipids: role in mitochondrial function. J Bioenerg Biomembr 48, 99-112.

Mohan S, Abdul AB, Abdelwahab SI, Al-Zubairi AS, Sukari MA, Abdullah R, Elhassan Taha MM, Ibrahim MY, Syam S (2010) Typhonium flagelliforme induces apoptosis in CEMss cells via activation of caspase-9, PARP cleavage and cytochrome c release: its activation coupled with G0/G1 phase cell cycle arrest. J Ethnopharmacol 131(3):592-600

Munoz N, Mendez F, Posso H, Molano M, van den Brule AJ, Ronderos M, Meijer C, Munoz A (2004) Incidence, duration, and determinants of cervical human papillomavirus infection in a cohort of Colombian women with normal cytological results. J Infect Dis 190:2077-2087

Okada H, Mak TW (2004) Pathways of apoptotic and non-apoptotic death in tumor cells. Nat Rev Cancer 4(8):592-603

Pilch H, Gunzel S, Schaffer U, Tanner B, Brockerhoff P, Maeurer M, Hockel M, Hommel G, Knapstein PG (2001) Human papillomavirus (HPV) DNA in primary cervical cancer and in cancer free pelvic lymph nodes-correlation with clinico-pathological parameters and prognostic significance. Zentralbl Gynakol 123 (2):91-101

Pisani P, Bray F, Parkin DM (2002) Estimates of the world-wide prevalence of cancer for 25 sites in the adult population. Int $\mathrm{J}$ Cancer 97(1):72-81

Qin Y, Pan X, Tang TT, Zhou L, Gong XG (2011) Anti-proliferative effects of the novel squamosamide derivative (FLZ) on HepG2 human hepatoma cells by regulating the cell cycle-related proteins are associated with decreased $\mathrm{Ca}(2+) / \mathrm{ROS}$ levels. Chem Biol Interact 193(3):246-253 
Spangle JM, Munger K (2010) The human papillomavirus type 16 E6 oncoprotein activates mTORC1 signaling and increases protein synthesis. J Virol 84(18):9398-9407

Stefanska J, Pawliczak R (2008) Apocynin: molecular aptitudes. Mediat Inflamm 2008:106507

Suzuki S, Pitchakarn P, Sato S, Shirai T, Takahashi S (2013) Apocynin, an NADPH oxidase inhibitor, suppresses progression of prostate cancer via Rac1 dephosphorylation. Exp Toxicol Pathol 65(7-8):1035-1041
Suzuki S, Shiraga K, Sato S, Punfa W, Naiki-Ito A, Yamashita Y, Shirai T, Takahashi S (2013) Apocynin, an NADPH oxidase inhibitor, suppresses rat prostate carcinogenesis. Cancer Sci 104 (12):1711-1717

Yu SP, Choi Dw (2000) Ions, cell volume, and apoptosis. Proc Natl Acad Sci USA 97:9360-9362

Zhang Y, Zhao W, Zhang HJ, Domann FE, Oberley LW (2002) Overexpression of copper zinc superoxide dismutase suppresses human glioma cell growth. Cancer Res 62(4):1205-1212 